Guest Editorial, part of a Special Feature on Beyond Social-Ecological Traps: Fostering Transformations towards Sustainability

\title{
Beyond social-ecological traps: fostering transformations towards sustainability
}

Hampus Eriksson $^{1,2}$, Jessica L. Blvthe $^{3}$, Henrik Österblom $^{4}$ and Per Olsson $^{4}$

ABSTRACT. This Special Feature is motivated by the rigorous, and growing, theoretical and empirical body of literature on socialecological traps. Building on the foundational literature, which describes the context in many of the places where we work, we now look forward and ask how we can better understand and enable the breaking and escaping of social-ecological traps. In this Special Feature we focus on this frontier in the field and use the trap metaphor as a unifying framework for collating empirically derived insights on overcoming challenges across diverse geographies, sectors, and social-ecological contexts. We requested contributions to this feature that, as well as possible under each context, explore tangible pathways for disrupting social-ecological traps. Thematic relevance and clear contribution to social-ecological scholarship was emphasized in the invited contributions, but authors were not constrained by methodological approach, context, geographical location, or sector. Our ambition with this editorial is to synthesize the novel insights these papers highlight and situate their contributions within the relevant literature.

Key Words: comanagement; gender; livelihoods

\section{INTRODUCTION}

Over the last decade, the notion of social-ecological traps has gained traction within resilience and sustainability science, to explain the rigidity of social and ecological processes that produce environmental degradation and entrenched poverty or marginalization (Steneck et al. 2011, Boonstra and Hanh 2015, Lade et al. 2017, Haider et al. 2018). Resilience scholars describe social-ecological traps as cases where social and ecological feedbacks reinforce one another to lock a social-ecological system into an undesirable state (Chapin et al. 2010, Österblom et al. 2011). The notion of social-ecological traps builds on the related, but separate, idea of poverty traps, which conceptualizes traps as detached from ecological dynamics (Carpenter and Brock 2008). In contrast, the concept of social-ecological traps is underpinned by the assumption that social and ecological components of a system are inextricably linked (Österblom et al. 2011, Schlüter et al. 2019). Human actions are understood to affect feedbacks in social-ecological systems, which in turn alter an ecosystems' capacity to generate services on which human well-being depends (Steneck et al. 2011).

Empirical case studies have helped shape our conceptualization of social-ecological traps. For example, in tropical reef fisheries, where poverty is high and local institutions weak, overfishing with destructive gear can push coral reef social-ecological systems past key thresholds by reducing coral cover and herbivorous fish (Cinner 2011). These processes can be reinforced by ecological feedbacks, such as the proliferation of macroalgae, thus locking the system into an undesirable state where overfishing results in poor yields and reef systems are further degraded (Cinner 2011, Nyström et al. 2012). Similarly, in Tanzania reduced availability of off-farm ecosystem services, changing smallholder farming practices, reduced rainfall, declining soil fertility, and repeated crop failures interact to lock semiarid farming systems into socialecological traps (Enfors 2013). Examples like these illustrate the complex interplay between social and ecological feedbacks that can lock communities into social-ecological traps.
Recent research has advanced the thinking about traps on several fronts. First, while conventional social-ecological trap research focused on a lack of capacity, new scholarship demonstrates that social-ecological interactions are complex, contextual, and mediated by differential opportunities (Boonstra et al. 2016, Lade et al. 2017). Individuals and communities' resource use, stewardship, and opportunities for equitable development are more appropriately understood as embedded in circumstances of poverty often shaped by external economic or political factors, as well as other issues (Blythe et al. 2013, Brugere et al. 2021). Second, the root drivers of social-ecological traps are known to be linked across scales. Local sustainability problems are often driven by global markets and multinational actors whose actions are depleting and degrading resources in ways that local people are ill-equipped to defend against (Blythe et al. 2015, Eriksson et al. 2016, Minter et al. 2018). For example, Nayak et al. (2014) demonstrate that broad-scale structural issues of economic exclusion, social marginalization, class exploitation, and political disempowerment are intertwined with local resource use. Multiscalar analysis usefully highlights the complexity of socialecological systems and consequently the difficulties involved in collaborative management of such systems. Third, socialecological traps are now understood as longitudinal processes that are the product of historical events, rather than static states (Boonstra and de Boer 2014). This focus on the temporal dynamics of social-ecological traps demonstrates that the combination of social and environmental events over time contributes profoundly to the production of trap processes.

This Special Feature is motivated by the rigorous, and growing, theoretical and empirical body of literature on social-ecological traps. Building on the foundational literature, which describes the context in many of the places where we work, we now look forward and ask how we can better understand and enable the breaking and escaping of social-ecological traps. In this Special Feature we focus on this frontier in the field and use the trap metaphor as a unifying framework for collating empirically derived insights on overcoming challenges across diverse geographies, sectors, and

${ }^{1}$ WorldFish, Honiara, Solomon Islands, ${ }^{2}$ Australian National Centre for Ocean Resources and Security (ANCORS), University of Wollongong, Australia, ${ }^{3}$ Environmental Sustainability Research Centre, Brock University, Canada, ${ }^{4}$ Stockholm Resilience Centre, Stockholm University, Sweden 
social-ecological contexts. We requested contributions to this feature that, as well as possible under each context, explore tangible pathways for disrupting social-ecological traps. Thematic relevance and clear contribution to social-ecological scholarship was emphasized in the invited contributions, but authors were not constrained by methodological approach, context, geographical location, or sector.

The result is a suite of articles, ranging from case studies to synthesis papers, that generate rich insights on overcoming this challenge of entrenchment. Two papers explore the critical role of Indigenous knowledge in supporting well-being and ecological sustainability (Eckert et al. 2018, Long and Lake 2018). Other articles analyze the disruptive potential of comanagement initiatives (Andrachuk et al. 2018, Hanh and Boonstra 2018, Steenbergen and Warren 2018, van Brakel et al. 2018). Two insightful articles highlight gender inequality as a social institution that inhibits sustainable development (Cole et al. 2018, Fröcklin et al. 2018). One paper explores the role of social networks in supporting transformational change when the current social-ecological conditions have become untenable (Barnes et al. 2017). Several articles focus or incorporate livelihood diversification projects and government service delivery (Ateweberhan et al. 2018, Baker et al. 2018, van Brakel et al. 2018, Eriksson et al. 2020). As a whole, the feature is rich with contributions to the field of social-ecological traps and systems thinking more broadly, sometimes straddling the themes of rural development and agricultural innovation systems. Although the articles are diverse, they nonetheless address common themes. Our ambition with this editorial is to synthesize the novel insights these papers highlight and situate their contributions within the relevant literature.

\section{PATHWAYS FOR DISRUPTING SOCIAL-ECOLOGICAL TRAPS}

Through synthesis of the papers in this Special Feature, we identify three pathways that have contributed to disrupting trap processes: (1) revitalize Indigenous knowledge and stewardship, (2) foster comanagement, and (3) empower women (Fig. 1). Here, we discuss the contributions of the articles in the Special Feature to advancing this scholarship.

\section{Revitalize Indigenous knowledge and stewardship}

Two articles in this Special Feature highlight the revitalization of Indigenous knowledge and stewardship as a critical pathway for breaking social-ecological traps (Eckert et al. 2018, Long and Lake 2018). These articles engage with the impact of colonization on Indigenous knowledge and culture, and the subsequent environmental degradation that ensued. They challenge conceptualizations of social-ecological traps that do not acknowledge the historical (and often external) drivers that lead to traps in which many contemporary communities find themselves. They highlight that solutions to external perturbations can come from restorative processes founded on Indigenous knowledge. Each of these articles asserts that the past continues to shape the present and that ignoring historical dynamics leaves us poorly equipped to address contemporary challenges. This is a pertinent message considering how time-scale dynamics shape traps (Boonstra and de Boer 2014).
Fig. 1. Three pathways for disrupting social-ecological traps highlighted by the papers in this Special Feature: (1) revitalize Indigenous knowledge and stewardship, (2) foster comanagement, and (3) empower women.

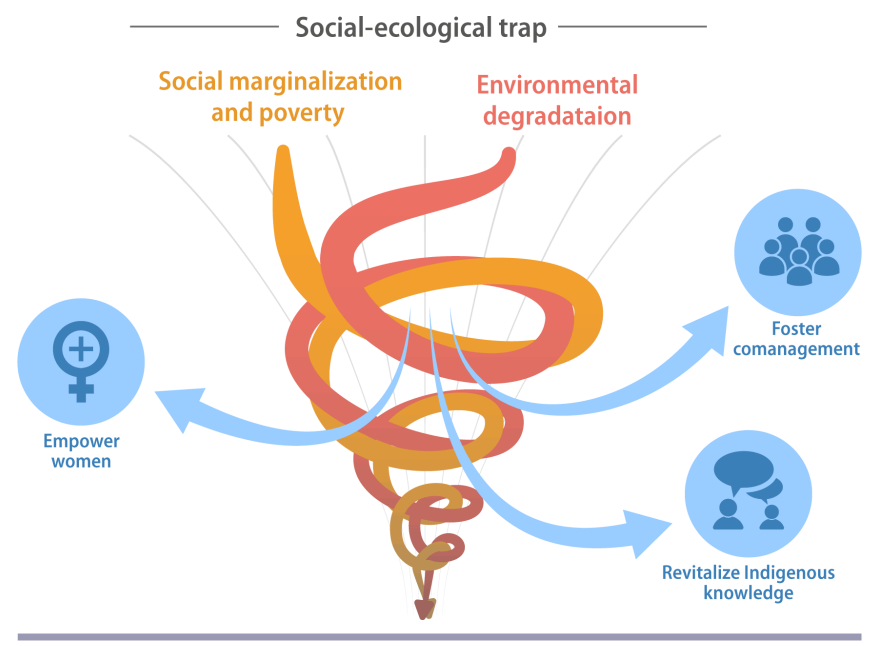

The paper by Eckert et al. (2018) demonstrates that cycles of social marginalization and environmental degradation on the central coast of British Columbia in Canada are externally driven. Centuries of colonialism resulted in the loss of Indigenous management rights and stewardship capacity. At the same time, industrial-scale fishing (made possible by colonial law that rendered Indigenous management illegal) led to the degradation of marine species. Decreased abundance of culturally important coastal resources, such as the yelloweye rockfish (Sebastes ruberrimus), further eroded Indigenous knowledge and culture. Participants in their research point to the integration of Indigenous knowledge into management plans and culturally based education systems as potential pathways towards increased well-being and sustainability. Their study describes ongoing cultural revitalization efforts, active recovery of depleted species, and reassertion of Indigenous management rights as effective ways of overcoming cycles of social-ecological injustice.

Long and Lake (2018) explore how historical relationships between Native American tribes and forests in the Pacific Northwest in the United States of America shaped socialecological traps. They also highlight how the restoration of tribal stewardship is fostering sustainability. Through a review of more than 300 documents, they describe how government policies displaced Native Americans from their traditional relationships with ancestral ecosystems. This, in turn, led to declines in ecosystem health and community well-being, along with a host of related challenges. They assert that breaking these complex and long-standing traps will require the return of public lands to tribal control and cooperative restoration efforts, among other strategies. Importantly, because tribally focused restoration strategies generally align with broader strategies suggested to restore national forests in the region, tribal stewardship initiatives can foster both tribal well-being and ecological sustainability. 


\section{Foster comanagement}

Articles in this Special Feature also highlight the role of comanagement as a critical pathway for breaking socialecological traps. Four papers highlight the limitations of topdown governance approaches for alleviating poverty and environmental degradation in complex rural settings and point to the potential of hybrid, decentralized management systems for building sustainability (Andrachuk et al. 2018, Baker et al. 2018, Steenbergen and Warren 2018, van Brakel et al. 2018). Importantly, each paper stresses that comanagement is not a panacea; there is no one-size fits all comanagement arrangement that will weaken social-ecological traps in all contexts. Yet, they do suggest several guiding principles for effective comanagement. First, they highlight the importance of securing local land rights. Second, all four articles find that comanagement is most effective when devolution of management authority is accompanied by adequate financial and human resources. Third, they demonstrate that comanagement needs to be tailored to ever evolving local contexts.

In Bangladesh, van Brakel et al. (2018) describe how debt to informal creditors and overfishing in a largely open access system perpetuated social-ecological traps for hilsa (Tenualosa ilisha) fishing households. The authors document how the implementation of comanaged fish sanctuaries has led to the recovery of hilsa stocks and biodiversity. They describe an adaptive comanagement system where local communities and fisher associations would be involved in monitoring and enforcing compliance of a seasonal hilsa fish ban as critical for weakening the trap. The success of this comanagement system is predicated on secure tenure rights and meaningful representation in resource management and decision making. Ultimately, the authors conclude that "providing small-scale fishers with the entitlements for local tenure and capabilities to make a living by responsible fishing or a choice of other livelihood options may be the most, if not only, viable trajectory toward disrupting trap dynamics in the Meghna River linked SES [social-ecological system]" (van Brakel et al. 2018).

In Ghana, many rural communities find themselves in persistent cycles of resource dependence, overexploitation, and unsustainable practices (Baker et al. 2018). In response, community-based resource management areas (CREMAs) are being implemented to secure natural resources and reduce poverty by offering opportunities for livelihood diversification. Baker et al. (2018) explore two cases of CREMAs and find that they facilitated collective discussions (between civil society groups, customary authorities, and state officials), the setting of shared priorities, and the formation of new governance arrangements. This paper emphasizes that although useful, comanagement was unable to fully break social-ecological traps and highlights the importance of secure land and resource tenure and recognition of customary management/authorities as necessary components of sustainable resource management. The CREMA supported training for farmers, e.g., processing techniques and soil fertility technologies, and the introduction of new trees and crops. Both cases in this paper highlight how insufficient devolution of (financial and human) resources in decentralized regimes undermines effective comanagement systems.
Based on a case study of a locally managed marine area in Indonesia, Steenbergen and Warren (2018) emphasize the role of community brokers and "institutional bricolage" in translating externally driven community-based fisheries management projects into locally appropriate and relevant terms. In the Tanimbar Islands, external project staff proposed a total prohibition on fishing. The community was resistant to this complete ban, in part because some of the prohibited species held important cultural value. Community brokers were able to help the parties navigate this misalignment and revise the regulations to allow for turtles to be consumed as part of traditional ceremonies. Steenbergen and Warren (2018) articulate that effective comanagement needs to be tailored to specific local norms, practices, and beliefs.

For Andrachuk et al. (2018), transformations to sustainability can be supported by building on governance success stories. Through the study of comanagement of the small-scale fisheries in Cau Hai Lagoon, Vietnam, the authors identify five building blocks that enabled fishers to break cycles of livelihood challenges and environmental degradation. The building blocks include: (1) fisher support for ecological conservation, (2) cooperation among fishers, (3) support from local government, (4) secure funding, and (5) effective leadership. The authors contend that while the building blocks are context specific, they provide generalizable lessons about the role of comanagement in weakening socialecological traps.

\section{Empower women}

Growing global support for gender equality comes, at least in part, from the recognition that gender inequality is not only a moral issue, it is also stifling development (UN General Assembly 2015). For example, the differential availability and access to assets and information by men and women shape their agency and ability to influence their well-being (Cohen et al. 2016). Although the need for achieving gender equality is agreed upon, making practical sense of the very complicated social fabric that underpins gender relationships is a challenging prospect (Lawless et al.2017). Externally supported initiatives often ignore, and may unintentionally reinforce, gendered power inequalities (Stacey et al. 2019). For example, community consultations to discuss resource management often involve only men. Women may not attend training workshops because the invitations are sent to community leaders or heads of households, roles typically held by men, or because the workshops are held at times or at places when women cannot attend because of their gendered responsibilities (Lawless et al. 2017). Still, the past decades have seen a rise in the recognition of women in rural development and small enterprise initiatives, and recently gender equality in global agricultural research for development was termed the "new normal” (CGIAR 2020).

In this Special Feature, Fröcklin et al. (2018) evaluate the impacts of a USAID program to build women's business and financial capacity around their shell-handicrafts in Zanzibar, Tanzania. The study finds that locally developed, small-scale innovations focusing on women's enterprises can have a measurable positive impact both on the women themselves by increasing their access to a range of assets, ranging from cell phones and freezers to entrepreneurial and marketing knowledge. The paper also 
highlights how increased access to assets among women also contributed to their surrounding social sphere through improvements in material well-being (Fröcklin et al. 2018).

Through a case study in Zambia, Cole et al. (2018) describe how strengthening women's fish processing skills and reducing unequal gender relations can improve food quality. Women operate as fish processors and traders along fish-supply routes in many parts of Zambia. Cole et al. (2018) describe a program that integrates technical innovation to reduce postharvest fish losses with social innovation to improve gender relations. Through this integrative way of tackling what initially may seem as a very technical problem - fish losses due to rudimentary processing and trading conditions - the small-scale fishery system becomes an entry point for gender transformative change (Cole et al. 2018).

These are important studies that provide tangible lessons for social-ecological traps and gender research and practice. Clearly, not every location where there is poverty and gender inequality will benefit from shell-handicrafts or innovations to reduce fish losses. However, identifying local opportunities and not being blind to gendered barriers are important, and generalizable, findings from these studies. Understanding how gendered structures underpin development challenges represents an important frontier for research and practice on breaking socialecological traps.

In addition to these pathways that are supported by two or more papers in the Special Feature, the paper by Barnes et al. (2017) suggests that social networks might also play an important role in breaking social-ecological traps. The capacity to adapt or transform has been identified as important for avoiding or breaking social-ecological traps (Engle 2011). Taking a social network perspective, Barnes et al. (2017) propose a framework that theorizes seven social-ecological network configurations that support effective adaptation and transformation within socialecological systems. They present the seven configurations along a spectrum from adaptation to transformation. They conclude with a call for empirical testing of their framework to advance scholarship on the role of social networks in facilitating adaptive or transformative change in the context of social-ecological traps and social-ecological systems resilience more broadly.

\section{CHALLENGES ASSOCIATED WITH DISRUPTING SOCIAL-ECOLOGICAL TRAPS}

Diverse livelihood assets increase the capabilities of rural households to raise their living standards, manage uncertainty, and possibly decrease direct dependence on natural resources (Allison and Ellis 2001, Ellis and Allison 2004). Livelihood diversification as a process is also highlighted as a potential strategy for disrupting trap dynamics (Haider et al. 2018). In this context, several papers in this Special Feature focused on livelihood diversification. However, the papers all point towards the limits of livelihood diversification as a pathway for escaping social-ecological traps. Or perhaps more specifically the studies help illustrate a conceptual muddiness about pragmatizing livelihood diversification as a process: they highlight some of the challenges associated with livelihood diversity narratives and programs that support it as a solution to entrenched poverty and environmental degradation.
In parts of the Western Indian Ocean, community-based aquaculture is being promoted as a livelihood diversification strategy, with the aim of minimizing overexploitation of marine fisheries and promoting biodiversity conservation (Ateweberhan et al. 2018). Through a workshop with 44 relevant stakeholders (including researchers, technicians and extension workers, commercial partners, CBA farmers, fishers, conservation ecologists, and university students) in Zanzibar and a literature review, Ateweberhan et al. (2018) find that the potential for smallscale aquaculture to alleviate poverty and environmental degradation is limited. They find that many projects are driven by external donors, rather than local entrepreneurs. Moreover, they find that small-scale aquaculture is constrained by a shortage of seed and feed supplies, low financial investments, limited technical capacity and skills, insufficient political support, and lack of a clear regional strategy for aquaculture development. These challenges are "compounded by a lack of engagement of local stakeholders, with decision making often dominated by donors, development agencies, and private sector partners" (Ateweberhan et al. 2018). Their paper points to the limited potential of the current small-scale aquaculture sector to weaken social-ecological traps in the Western Indian Ocean.

In rural Solomon Islands, Eriksson et al. (2020) find that both quantitative and qualitative approaches to identify which livelihoods options to prioritize for livelihood initiatives have limitations. Communities in the study area have established a locally marine managed area to address shared concerns over unsustainable fishing and other environmental threats to livelihoods (Sulu et al. 2015, Sukulu et al. 2016). In this process the conversation among community members focused on alternative livelihoods while reefs and mangroves are closed (Teioli et al. 2018). It became clear to the leaders who were seeking to organize communities around the managed area that people involved lived very different lives; so how to identify an activity that would somehow serve all impacted by the sustainability initiative? The study highlights that even though we have developed a much richer understanding along with the methodological advances in analyzing how people live their lives, we are still grappling with "what option is best, and for whom?" (Scoones 2009:185). The study raises a suite of questions around how to quantify and interpret the complex patterns of how people live their lives and incorporate this knowledge into the design of credible theories of change for development and conservation initiatives that focus on livelihood diversification.

Hanh and Boonstra (2018) evaluate income diversification as a way to weaken social-ecological traps in small-scale fisheries and aquaculture in the Global South, through a case study in the Tam Giang lagoon, in Vietnam. They find that livelihood diversification, which in their case occurred primarily through work in fisheries, aquaculture, and some paid labor, improved peoples' well-being. Yet, diversification also increased socialecological vulnerability. For example, "well-being deteriorated whenever there were changes related to the lagoon ecology, such as during the collapse of aquaculture from 2004 to 2006 and an ecological disaster in 2016" (Hanh and Boonstra 2018). They also highlight that improvements in well-being, made through livelihood diversification, came at the expense of the sustainability of lagoon resources. Their paper, therefore, calls for 
closer attention to the textures of diversity using Stirling's (2007) framework that unpacks diversity into variety, balance, and disparity. The analysis of livelihood change using this framing evolves the research around diversified livelihoods and, importantly, to how livelihood activities are connected to natural environments.

\section{CONCLUDING REMARKS}

The concept of social-ecological traps has been applied in a diversity of settings to uncover the processes that contribute to, or alleviate, the close coupling of poverty and environmental degradation. The studies in this Special Feature applied a socialecological lens to case studies ranging from women's production of shell handicrafts in Zanzibar, Tanzania to Indigenous stewardship in western Canada. Synthesis of the articles in the Special Feature revealed three pathways for breaking socialecological traps: (1) revitalize Indigenous knowledge and stewardship, (2) foster co-management, and (3) empower women. The papers also highlight that untangling what is meant by livelihood diversification and its processes will be important to better gauge how it can actually weaken social-ecological traps in the Western Indian Ocean, Vietnam, and Solomon Islands. In addition to these findings, we would like to highlight three points to conclude the Special Feature.

First, social-ecological traps emerge from multiscalar processes, and structural drivers often originate outside the local scale or community (Boonstra and de Boer 2014, Boonstra et al. 2016). In Canada and the United States, for example, processes of colonization disrupted Indigenous relationships with ancestral land, which led to environmental degradation, and further loss of Indigenous stewardship (Eckert et al. 2018, Long and Lake 2018). In Ghana, illegal logging to supply global demand for rosewood was responsible for deforestation in the Akwapim-Togo Mountain Range (Baker et al. 2018). The contemporary examples in this Special Feature illustrate critiques from more than two decades ago, which showed that poor people do not degrade the environment because they are poor; rather environments are degraded as the result of external processes of international market demands, colonial histories, and power imbalances where rich countries and companies offset their environmental footprint in less powerful places (Fairhead and Leach 1996, Ferguson 1990).

Second, the pathways that we organize this editorial around are not discrete or exhaustive. Also, none of the pathways for breaking social-ecological traps we present are separate. We separate them for analytical clarity. For example, Steenbergen and Warren (2018) argue that effective comanagement (pathway 2) is built through hybrid practices that merge traditional ways of knowing and managing with Western scientific knowledge (pathway 1). Similarly, Lake and Long (2018) discuss the reintroduction of fire into forest management regimes by drawing on traditional ecological knowledge (pathway 1) through adaptive comanagement (pathway 2). Building on Lade et al. (2017), future research should continue to explore the influence of interacting pathways on making or breaking social-ecological traps.

Third, we hope that one of the contributions of publishing these studies together in a Special Feature is that they highlight the unique and complex nature of each context. Greater attention (in science, policy, and practice) is needed to ensure equal opportunity, voice, agency, access, and sharing of benefits, also for women, indigenous groups, and local communities. We recognize that reform in the power dynamics of knowledge systems, governance approaches, and social institutions will necessarily produce uneven impacts within and across contexts (Blythe et al. 2018). Rather than prescribing solutions then, the pathways presented here seek to highlight potential points of departure for change that may improve human well-being and environmental sustainability. However, moving beyond socialecological traps and supporting transformative change will require capacities to break down the structures that keep the system in a trap but also to experiment with and scale alternative, regenerative approaches (Herrfahrdt-Pähle et al. 2020).

The social-ecological trap language has created a scientific metaphor that can simplify complex processes for analyses and potentially action, yet it is still a clumsy representation of reality. In the process of studying and describing complex, dynamic contexts, we clearly create imperfect representations of reality, which may inhibit us to truly understand the choices that people make and the institutions that govern people's behavior and conduct. This Special Feature does not claim to solve the challenges associated with entrenched social-ecological traps, but rather aims to contribute to the applied research frontier of understanding impacts and development in areas where livelihoods and natural resources are tightly coupled.

Responses to this article can be read online at: https://www.ecologyandsociety.org/issues/responses. $\mathrm{php} / 12198$

\section{Acknowledgments:}

This Special Feature was convened under the CGIAR research program of Fish in Agri-Food systems (FISH) led by WorldFish. The thinking and action that led to this feature was brought together under an initiative funded by SwedBio, a programme at the Stockholm Resilience Centre, and the Australian Centre for International Agricultural Research (ACIAR) project FIS/2016/300. We thank our colleagues Neil Andrew and Max Troell for their input on the scope of the Special Feature and this editorial.

\section{LITERATURE CITED}

Allison, E. H., and F. Ellis. 2001 The livelihoods approach and management of small-scale fisheries. Marine Policy 25:377-388. https://doi.org/10.1016/s0308-597x(01)00023-9

Andrachuk, M., D. Armitage, H. Dung Hoang, and N. Van Le. 2018. Building blocks for social-ecological transformations: identifying and building on governance successes for small-scale fisheries. Ecology and Society 23(2):26. https://doi.org/10.5751/ ES-10006-230226

Ateweberhan, M., J. Hudson, A. Rougier, N. S. Jiddawi, F. Msuya, S. M. Stead, and A. Harris. 2018. Community based aquaculture in the western Indian Ocean: challenges and opportunities for developing sustainable coastal livelihoods. Ecology and Society 23(4):17. https://doi.org/10.5751/ES-10411-230417 
Baker, D. M., G. Murray, and A. Agyare. 2018. Governance and the making and breaking of social-ecological traps. Ecology and Society 23(1):38. https://doi.org/10.5751/ES-09992-230138

Barnes, M. L., Ö. Bodin, A. M. Guerrero, R. J. McAllister, S. M. Alexander, and G. Robins. 2017. The social structural foundations of adaptation and transformation in social-ecological systems. Ecology and Society 22(4):16. https://doi.org/10.5751/ES-09769-220416

Blythe, J., M. Flaherty, and G. Murray. 2015. Vulnerability of coastal livelihoods to shrimp farming: insights from Mozambique. Ambio 44(4):275-284. https://doi.org/10.1007/ $\underline{\text { s13280-014-0574-Z }}$

Blythe, J. L., G. Murray, and M. S. Flaherty. 2013. Historical perspectives and recent trends in the coastal Mozambican fishery. Ecology and Society 18(4):65. https://doi.org/10.5751/ES-05759-180465

Blythe, J., J. Silver, L. Evans, D. Armitage, N. J. Bennett, M.-L. Moore, T. H. Morrison, and K. Brown. 2018. The dark side of transformation: latent risks in contemporary sustainability discourse. Antipode 50(5):1206-1223. https://doi.org/10.1111/ anti.12405

Boonstra, W. J., E. Björkvik, L. J. Haider, and V. Masterson. 2016. Human responses to social-ecological traps. Sustainability Science 11:877-889. https://doi.org/10.1007/s11625-016-0397-x

Boonstra, W. J., and F. W. de Boer. 2014. The historical dynamics of social-ecological traps. Ambio 43:260-274. https://doi. org/10.1007/s13280-013-0419-1

Boonstra, W. J., and T. T. H. Hanh. 2015. Adaptation to climate change as social-ecological trap: a case study of fishing and aquaculture in the Tam Gian Lagoon, Vietnam. Environment, Development and Sustainability 17:1527-1544. https://doi. org/10.1007/s10668-014-9612-Z

Brugere, C., M. Troell, and H. Eriksson. 2021. More than fish: policy coherence and benefit sharing as necessary conditions for equitable aquaculture development. Marine Policy 123:104271. https://doi.org/10.1016/j.marpol.2020.104271

Carpenter, S. R., and W. A. Brock. 2008. Adaptive capacity and traps. Ecology and Society 13(2):40. https://doi.org/10.5751/ ES-02716-130240

CGIAR. 2020. Gender equality in food systems: the "new normal. ' CGIAR Gender Platform, CGIAR, Montpellier, France. [online] URL: https://gender.cgiar.org/gender-equality-in-foodsystems-the-new-normal/

Chapin III, F. S., S. R. Carpenter, G. P. Kofinas, C. Folke, N. Abel, W. C. Clark, P. Olsson, D. M. Stafford Smith, B. Walker, O. R. Young, F. Berkes, R. Biggs, J. M. Grove, R. L. Naylor, E. Pinkerton, W. Steffen, and F. J. Swanson. 2010. Ecosystem stewardship: sustainability strategies for a rapidly changing planet. Trends in Ecology and Evolution 25:241-249. https://doi. org/10.1016/j.tree.2009.10.008

Cinner, J. E. 2011. Social-ecological traps in reef fisheries. Global Environmental Change 21:835-839. https://doi.org/10.1016/j. gloenvcha.2011.04.012

Cohen, P. J., S. Lawless, M. Dyer, M. Morgan, E. Saeni, H. Teioli, and P. Kantor. 2016. Understanding adaptive capacity and capacity to innovate in social-ecological systems: applying a gender lens. Ambio 45:309-321. https://doi.org/10.1007/ s13280-016-0831-4

Cole, S. M., C. McDougall, A. M. Kaminski, A. S. Kefi, A. Chilala, and G. Chisule. 2018. Postharvest fish losses and unequal gender relations: drivers of the social-ecological trap in the Barotse Floodplain fishery, Zambia. Ecology and Society 23 (2):18. https://doi.org/10.5751/ES-09950-230218

Eckert, L. E., N. C. Ban, S.-C. Tallio, and N. Turner. 2018. Linking marine conservation and Indigenous cultural revitalization: First Nations free themselves from externally imposed socialecological traps. Ecology and Society 23(4):23. https://doi. org/10.5751/ES-10417-230423

Ellis, F., and E. Allison. 2004. Livelihood diversification and natural resource access. FAO Livelihood Support Programme Working Paper 9. Food and Agriculture Organization of the United Nations, Rome, Italy.

Enfors, E. 2013. Social-ecological traps and transformations in dryland agro-ecosystems: using water system innovations to change the trajectory of development. Global Environmental Change 23(1):51-60. https://doi.org/10.1016/j.gloenvcha.2012.10.007

Engle, N. L. 2011. Adaptive capacity and its assessment. Global Environmental Change 21:647-656. https://doi.org/10.1016/j. gloenvcha.2011.01.019

Eriksson, H., D. S. Adhuri, L. Adrianto, N. L. Andrew, T. Apriliani, T. Daw, L. Evans, L. Garces, E. Kamanyi, R. Mwaipopo, A. H. Purnomo, R. J. Sulu, and D. J. Beare. 2016. An ecosystem approach to small-scale fisheries through participatory diagnosis in four tropical countries. Global Environmental Change 36:56-66. https://doi.org/10.1016/j.gloenvcha.2015.11.005

Eriksson, H., R. Sulu, J. L. Blythe, J. van der Ploeg, and N. Andrew. 2020. Intangible links between household livelihoods and food security in Solomon Islands: implications for rural development. Ecology and Society 25(4):18. https://doi. org/10.5751/ES-11709-250418

Fairhead, J., and M. Leach. 1996. Misreading the African landscape: society and ecology in a forest-savanna mosaic Vol. 90. Cambridge University Press, Cambridge, UK. https://doi. org/10.1017/CBO9781139164023

Ferguson, J. 1990. The anti-politics machine: "development," depoliticization, and bureaucratic power in Lesotho. Cambridge University Press, Cambridge, UK.

Fröcklin, S., N. S. Jiddawi, and M. De la Torre-Castro. 2018. Small-scale innovations in coastal communities: shell-handicraft as a way to empower women and decrease poverty. Ecology and Society 23(2):34. https://doi.org/10.5751/ES-10136-230234

Haider, L. J., W. Boonstra, G. D. Peterson, and M. Schlüter. 2018. Traps and sustainable development in rural areas: a review. World Development 101:311-321. https://doi.org/10.1016/j.worlddev.2017.05.038

Hanh, T. T. H., and W. J. Boonstra. 2018. Can income diversification resolve social-ecological traps in small-scale fisheries and aquaculture in the global south? A case study of response diversity in the Tam Giang lagoon, central Vietnam. Ecology and Society 23(3):16. https://doi.org/10.5751/ES-10207-230316 
Herrfahrdt-Pähle, E., M. Schlüter, P. Olsson, C. Folke, S. Gelcich, and C. Pahl-Wostl. 2020. Sustainability transformations: sociopolitical shocks as opportunities for governance transitions. Global Environmental Change 63:102097. https://doi.org/10.1016/ j.gloenvcha.2020.102097

Lade, S. J., L. J. Haider, G. Engström, and M. Schlüter. 2017. Resilience offers escape from trapped thinking on poverty alleviation. Science Advances 3(5):e1603043. https://doi. org/10.1126/sciadv. 1603043

Lawless, S., K. Doyle, P. Cohen, H. Eriksson, A. M. Schwarz, H. Teioli, A. Vavekaramui, E. Wickham, R. Masu, R. Panda, and C. McDougall. 2017. Considering gender: practical guidance for rural development initiatives in Solomon Islands. Program Brief: 2017-22. WorldFish, Penang, Malaysia.

Long, J. W., and F. K. Lake. 2018. Escaping social-ecological traps through tribal stewardship on national forest lands in the Pacific Northwest, United States of America. Ecology and Society 23 (2):10. https://doi.org/10.5751/ES-10041-230210

Minter, T., G. Orirana, D. Boso, and J. van der Ploeg. 2018. From happy hour to hungry hour: logging, fisheries and food security in Malaita, Solomon Islands. WorldFish, Penang, Malaysia.

Nayak, P. K., L. E. Oliveira, and F. Berkes 2014. Resource degradation, marginalization, and poverty in small-scale fisheries: threats to social-ecological resilience in India and Brazil. Ecology and Society 19(2):73. https://doi.org/10.5751/ES-06656-190273

Nyström, M., A. V. Norström, T. Bleckner, M. de la Torre-Castro, J. S. Eklöf, C. Folke, H. Österblom, R. S. Steneck, M. Thyresson, and M. Troell. 2012. Confronting feedbacks of degraded marine ecosystems. Ecosystems 15:695-710. https://doi.org/10.1007/ $\underline{\text { s10021-012-9530-6 }}$

Österblom, H., M. Sissenwine, D. Symes, M. Kadin, T. Daw, C. Folke. 2011. Incentives, social-ecological feedbacks and European fisheries. Marine Policy 35:568-574. https://doi. org/10.1016/j.marpol.2011.01.018

Schlüter, M., L. J. Haider, S. J. Lade, E. Lindkvist, R. Martin, K. Orach, N. Wijermans, and C. Folke. 2019. Capturing emergent phenomena in social-ecological systems: an analytical framework. Ecology and Society 24(3):11. https://doi. org/10.5751/ES-11012-240311

Scoones, I. 2009. Livelihoods perspectives and rural development. Journal of Peasant Studies 36:171-196. https://doi. org/10.1080/03066150902820503

Stacey, N., E. Gibson, N. R. Loneragan, C. Warren, B. Wiryawan, D. Adhuri, and R. Fitriana. 2019. Enhancing coastal livelihoods in Indonesia: an evaluation of recent initiatives on gender, women and sustainable livelihoods in small-scale fisheries. Maritime Studies 18:359-371. https://doi.org/10.1007/s40152-019-00142-5

Steenbergen, D. J., and C. Warren. 2018. Implementing strategies to overcome social-ecological traps: the role of community brokers and institutional bricolage in a locally managed marine area. Ecology and Society 23(3):10. https://doi.org/10.5751/ ES-10256-230310
Steneck, R. S., T. P. Hughes, J. E. Cinner, W. N. Adger, S. N. Arnold, F. Berkes, S. A. Boudreau, K. Brown, C. Folke, L. Gunderson, et al. 2011. Creation of a gilded trap by the high economic value of the Maine lobster fishery. Conservation Biology 25:904-912. https://doi.org/10.1111/j.1523-1739.2011.01717.x

Stirling, A. 2007. A general framework for analysing diversity in science, technology and society. Journal of the Royal Society Interface 4(15):707-719. https://doi.org/10.1098/rsif.2007.0213

Sukulu, M., G. Orirana, D. Oduagalo, B. Waleilia, R. J. Sulu, A. M. Schwarz, J. van der Ploeg, and H. Eriksson. 2016. 'Management over ownership': towards community-based natural resource management in Langalanga Lagoon, Solomon Islands. SPC Traditional Marine Resource Management and Knowledge Information Bulletin 37:13-21.

Sulu, R. J., H. Eriksson, A.-M. Schwarz, N. L. Andrew, G. Orirana, M. Sukulu, J. Oeta, D. Harohau, S. Sibiti, A. Toritela, and D. Beare. 2015. Livelihoods and fisheries governance in a contemporary Pacific Island setting. PLoS ONE 10(11): e0143516. https://doi.org/10.1371/journal.pone.0143516

Teioli, H. M., J. van der Ploeg, A. M. Schwarz, M. Sukulu, and H. Eriksson. 2018. Conserving womangroves: assessing the impacts of improved cooking stoves on resource management in Langalanga Lagoon, Solomon Islands. SPC Women in Fisheries Information Bulletin 28:8-14.

UN General Assembly. 2015. Transforming our world: the 2030 Agenda for Sustainable Development. UN General Assembly, New York, New York, USA.

van Brakel, M. L., M. Nahiduzzaman, A. Mahfuzul Haque, M. Golam Mustafa, M. Jalilur Rahman, and M. Abdul Wahab. 2018. Reimagining large-scale open-water fisheries governance through adaptive comanagement in hilsa shad sanctuaries. Ecology and Society 23(1):26. https://doi.org/10.5751/ES-09917-230126 